\title{
Mechanisms Underlying the Osteo- and Adipo-Differentiation of Human Mesenchymal Stem Cells
}

\author{
Yu Zhang, Dilaware Khan, Julia Delling, and Edda Tobiasch \\ Department of Natural Sciences, Bonn-Rhine-Sieg University of Applied Sciences, von-Liebig-Straße 20, 53359 Rheinbach, Germany \\ Correspondence should be addressed to Edda Tobiasch, edda.tobiasch@h-brs.de
}

Received 31 August 2011; Accepted 15 October 2011

Academic Editors: J.-T. Cheng, J. M. Nesland, and V. Pistoia

Copyright $\odot 2012$ Yu Zhang et al. This is an open access article distributed under the Creative Commons Attribution License, which permits unrestricted use, distribution, and reproduction in any medium, provided the original work is properly cited.

Human mesenchymal stem cells (hMSCs) are considered a promising cell source for regenerative medicine, because they have the potential to differentiate into a variety of lineages among which the mesoderm-derived lineages such adipo- or osteogenesis are investigated best. Human MSCs can be harvested in reasonable to large amounts from several parts of the patient's body and due to this possible autologous origin, allorecognition can be avoided. In addition, even in allogenic origin-derived donor cells, hMSCs generate a local immunosuppressive microenvironment, causing only a weak immune reaction. There is an increasing need for bone replacement in patients from all ages, due to a variety of reasons such as a new recreational behavior in young adults or age-related diseases. Adipogenic differentiation is another interesting lineage, because fat tissue is considered to be a major factor triggering atherosclerosis that ultimately leads to cardiovascular diseases, the main cause of death in industrialized countries. However, understanding the differentiation process in detail is obligatory to achieve a tight control of the process for future clinical applications to avoid undesired side effects. In this review, the current findings for adipo- and osteo-differentiation are summarized together with a brief statement on first clinical trials.

\section{Stem Cells}

Stem cells are defined as a type of pluripotent or multipotent cells, which have two typical features: self-renewal and have the potential to differentiate into several different cell lineages. According to the source they are obtained from, stem cells can be classified into embryonic stem cells (ESCs) which are isolated from the inner cell mass of blastocysts and adult stem cells found in various tissues of the mature organism. Adult stem cells are divided mainly into hematopoietic stem cells (HSCs) and mesenchymal stem cells (MSCs), but various other stem- and precursor cells have been found in a variety of different organs or tissues in the last years such as neural stem cells or skin stem cells [1-4]. Compared to ESCs that have the potency to differentiate into all kinds of cells lineages, these adult stem cells can only differentiate into several lineages. For instance, HSCs can differentiate into the cells blood which is composed of monocytes, neutrophils, lymphocytes, erythrocytes, and platelets [5]. More recently, a new and interesting source of stem cells has been created by Takahashi and Yamanaka named induced pluripotent stem cells (iPS) [6]. iPS are obtained by genetic reprogramming of differentiated somatic cells of adult tissue using pluripotent factors like Oct4, Sox2, Klf4, and c-myc $[7,8]$ or Oct4, Sox2, Lin28, and Nanog [9]. Depending on the tissue source, they can even be generated by only one factor $[10,11]$. They are regarded as a promising stem cell source for future repair of tissues or organs, especially since they are ethically not problematic. However, together with ESCs, iPS can easily form teratomas [12] and seem to be immunogenetically active after transplantation into the host [13]. In contrast, MSCs show some unique features: they are immunosuppressive and immunoprivileged [14]. They also show no detectable teratoma formation, high migration and motility and further display feasibility and safety use in vivo in clinic trials so far [15-18].

\section{Multilineage Differentiation Potential of Mesenchymal Stem Cells}

2.1. The Mesenchymal Stem Cell Character. MSCs are adult stem cells, which can self-renew and stay in the 


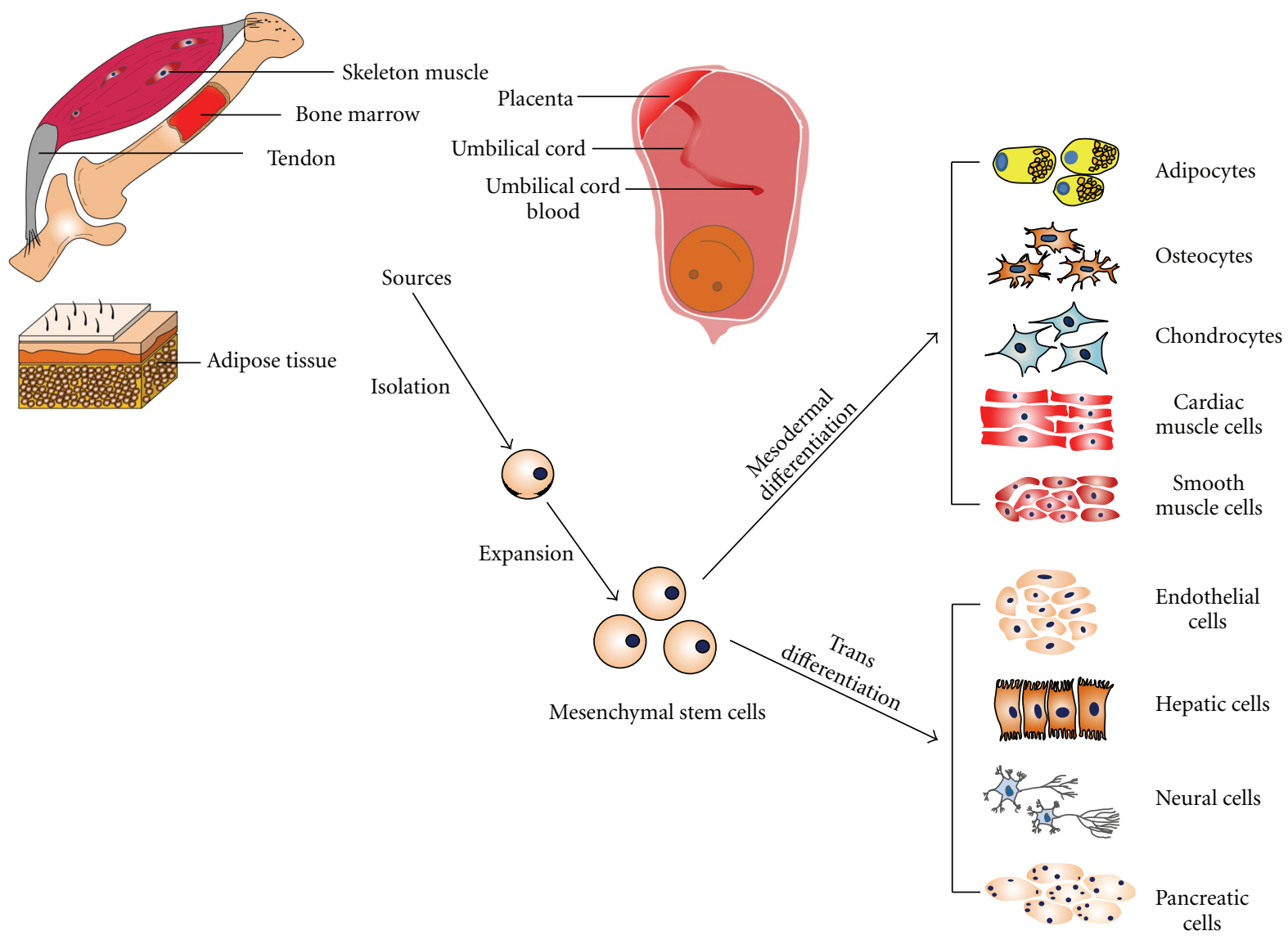

Figure 1: Multipotent Differentiation of Mesenchymal Stem Cells from Different Sources. MSCs can be obtained from skeleton muscle, bone marrow, tendon, adipose tissue, placenta, umbilical cord, and umbilical cord blood. MSCs have the potential to generate mesodermal lineages such as adipocytes, osteoblasts, and chondrocytes; on the other hand, they can also trans-differentiate into some cells lineages from other germ layers such as adipocytes, osteocytes, chondrocytes, cardiac muscle cells smooth muscle cells, and endothelial cells form mesodermal layer, neural cells from ectodermal layer, and hepatic cells and pancreatic cells from endodermal layer.

"undifferentiated" state due to some intrinsic or extrinsic suppressed factors until activated [19-22]. MSCs have been originally isolated from bone marrow (BM) $[23,24]$, and later similar populations were successfully harvested from other adult tissues such as adipose tissue (AT), tendon, peripheral blood (PB), skeleton muscle (SM), and recently from the trabecular bone [25-28]. At the same time, they can be generated from some neonatal tissues, umbilical cord (UC), umbilical cord blood (UCB), and particular parts of the placenta $[29,30]$ (see Figure 1). Although MSCs derived from bone marrow (BM-MSC) were first obtained and largely studied and used, MSC generated from AT (ATMSC), PB (PB-MSC), and UCB (UCB-MSC) do not need an invasive procedures for isolation compared to $\mathrm{BM}$-derived cells [31]. However, with the rising number of isolation procedures and the use of different sources, there is an important and urgent issue that need to be solved to compare the outcomes: the definition of an international standard for the MSC character [32]. In 2006, the International Society of Cellular Therapy (ISCT) proposed minimal criteria for defining mesenchymal stem cells: these cells can adhere to the plastic under standard culture condition. They positively express CD73 (SH2), CD90, and CD105 (SH3) and negatively express CD34, CD45, CD14 or CD11b, CD79 $\alpha$, or CD19 and HLA-DR. In addition, they should have the multipotency to differentiate into osteoblasts, adipocytes, and chondrocytes in vitro as demonstrated by specific stainings [33].

2.2. Source Difference and Comparison of the MSCs from Different Sources. MSCs derived from different sources pose same or similar features. However, many publications have reported that they have some differences in their proliferation rates, surface marker expressions, multipotency, and some other specific markers. This might be used to find the best source of MSCs to address specific qualities for replacement strategies in regenerative medicine [34, 35]. Generally, MSCs obtained from neonatal tissues have the significant advantage of avoiding invasive procedures which are usually accompanied with infection risk if compared to those from adult tissues [31]. They also show higher expansion and engraftment capacities compared to MSCs derived from $\mathrm{BM}[36,37]$. On the other hand, the success rate of isolation was only $63 \%$ from UCB if compared to those derived from BM and AT. Interestingly, MSCs derived from UCB seem not to have the capacity to differentiate towards 
the adipogenic lineage $[38,39]$. The proliferation capacity was higher in UC-MSCs than in BM-MSCs, and contact inhibition was observed in BM-MSCs but not in UC-MSCs [40, 41]. MSCs derived from cartilage exhibited the highest resistance against hydrogen peroxide-induced apoptosis, and AT-MSCs pose the highest proliferation rate and tolerance to serum deprivation-induced apoptosis [42]. The doubling time of population of AT-MSCs is 3/4 of BM-MSCs. ATMSCs also have different doubling times if derived from different regions [43, 44]. For example, AT-MSCs derived from omental regions proliferated slower than those from subcutaneous region [45]. MSCs from BM and placenta were shown to have a higher migration capacity than those from UC. This seemed to be regulated by increased expression of cathepsin B, cathepsin D, prohibitin and decreased expression of plasminogen activator inhibitor-1 (PAI-1), and manganese superoxide dismutase [46]. UCB-MSCs need shorter time to differentiate into osteogenic lineages than BM-MSCs [47]. Compared to adult-tissue-derived MSCs, neonatal MSCs also have a stronger immunosuppressive capacity and show lower immunogenicity. Therefore, they seemed to be a very reasonable source for therapeutic applications [48].

BM-MSC and AT-MSC are the two most frequently investigated MSCs. AT-MSCs can be obtained as a population of 5000 cells from one gram adipose tissue compared to only about $0.01 \%$ cells isolated from the interface after density gradient centrifugation of bone marrow aspirates. This means 500 times more cells can be obtained from AT than from equal amounts of BM [3, 49]. No remarkable difference in their morphology and immune phenotype was observed in BM-MSC and AT-MSCs [50]. But later Peng and colleagues reported that BM-MSCs are larger than AT-MSC [42], and that their proliferative activity is higher than BMMSCs [42, 51]. Some surface antigen expressions differ in BM-MSC and AT-MSC: CD49d, CD54, CD34, and CD106. CD49d was expressed only in AT-MSC, and the expression of CD106 was detected only in BM-MSCs $[26,52]$. The expression of chemokine receptors such as CCR1, CCR7, CXCR4, CXCR6 was increased in AT-MSCs compared to BM-MSCs [53]. By using a human genome microarray, 25 genes were predominantly up-regulated in BM-MSCs, AT-MSCs and UCB-MSCs compared to fibroblasts [54]. Additionally, they found that the mesoderm-specific transcript homolog (MEST) is expressed highest in BM-MSC and the connective tissue growth factor (CTGF), and the BMP antagonist 1 expressions are highest in UCB-MSC. At the same time, cyclin B2 (CCNB2), cell division cycle associated 8 (CDCA8), and $\mathrm{Ki}-67$ were higher expressed in AT-MSC, which indicates that AT-MSC might have the highest proliferative capacity. This result may explain the above findings that AT-MSCs multiplied faster than BM-MSCs $[42,51]$. Meanwhile cell population, maximal life span, and multipotential of BMMSC decrease with increasing the donor's age $[55,56]$. These differences of MSCs (summarized in Table 1) could be due to the region they are derived from or due to different isolated methods. In summary, MSCs isolated from adipose tissue can express all typical markers, simultaneously be isolated in large amount without additional pain or highly invasive procedures, and show strong apoptosis tolerance. Therefore, they are used and investigated as important and promising stem cells for regenerative medicine [57].

\subsection{Mesodermal Differentiation and Transdifferentiation.} Due to mainly mesodermal origin derived, mesenchymal stem cells always were regarded as an attractive source for differentiating into cells of this source such as osteoblasts (bone), adipocytes (fat tissue), and chondrocytes (cartilage) [35]. Recently some publications reported that MSCs also have the potential to differentiate into several additional cell lineages from the mesoderm. For example, MSCs derived from different regions showed myogenic potential and can differentiate into muscle lineages like skeleton muscle cells [58-60], smooth muscle cells [61-63], and cardiac muscle cells [64]. Interestingly, MSCs can differentiate into cells derived from other germ layers as well (see Figure 1). For example, MSCs can differentiate into neuron-like cells in vitro $[65,66]$, and into astrocytes and neurons after implanting into the mouse brain in vivo [67]. Hepatocytelike cells can also be generated from MSCs in vitro and in vivo $[68,69]$. MSCs pose the ability to differentiate into endothelial cells too $[61,70]$. They have also been considered a good source for insulin producing cells, which could be applied for diabetes therapy [71, 72]. The reason for this might be that although MSCs are originated from mesoderm, they have parts which are originated from other germ layers as well. Other authors describe this phenomenon as "transdifferentiation", meaning that stem cells differentiate into cells from another germinal layer the stem cells are derived from. Transdifferentiation, although not applicable to mesenchymal stem cells, is a widely used term often to doubt a specific differentiation since lineage commitment is thought to be not reversible until iPS came up [73]. On the other hand, the physical properties of the scaffold can also determine MSC differentiation [74]. For example, MSCs cultured in stiff scaffolds are easily differentiated into osteoblasts, and with the decrease of elasticity, MSCs showed the potential of myogenic, adipogenic and neurogenic differentiation, respectively [75]. To make a long story short, MSC fate is influenced by their environment, including growth factors, mechanical or physical stimulation, cell-cell attachment or interactions, and cell density [76]. However, this multipotency of MSCs might also be due to another reason, which is also postulated for UCB and wildly discussed. MSCs might not be pure and specific adult stem cells, but instead they might be a diverse mixture of many specific lineage progenitor cells [77].

2.4. Osteogenic Differentiation of MSCs. Multipotent stem cells such as MSCs express markers of multiple cell lineages [78]. These markers keep the cells in an undifferentiated state through negative feedback mechanisms. To commit the cells towards a specific lineage cytokines in vivo and induction factors in vitro is necessary. To induce in vitro osteogenesis of MSCs, combinations of different induction factors have been suggested (Table 2). In addition to supplements added to the basal medium, other techniques to optimize osteogenic 
TABLE 1: Comparison of MSCs derived from different sources.

\begin{tabular}{|c|c|c|c|}
\hline & Bone marrow & Adipose tissue & Other sources \\
\hline \multirow[t]{2}{*}{ Isolated methods } & $\begin{array}{l}\text { painful with invasive } \\
\text { procedure }\end{array}$ & $\begin{array}{l}\text { not additional pain; less invasive } \\
\text { procedure }\end{array}$ & $\begin{array}{l}\text { no pain; no invasive procedure } \\
\text { from UCB, CB placenta }\end{array}$ \\
\hline & $100 \%$ success rate & $100 \%$ success rate & $63 \%$ success rate \\
\hline Surface antigens or markers & $\begin{array}{l}\text { CD106 MEST higher } \\
\text { expression }\end{array}$ & $\begin{array}{l}\text { CD49b, CD54, CD34; Ki-67, } \\
\text { CDCA8, CCNB2 higher } \\
\text { expression; chemokine receptors }\end{array}$ & $\begin{array}{l}\text { CTGF, BMP antagonist } 1 \text { high } \\
\text { expression in UC-MSCs }\end{array}$ \\
\hline Differentiation potential & not restricted & not restricted & $\begin{array}{l}\text { stronger osteogenic differentiation } \\
\text { of UCB-MSCs; no adipogenic } \\
\text { differentiation of UCB-MSCs }\end{array}$ \\
\hline Proliferation & lowest & highest & high in CB-MSCs \\
\hline Migration capacity & high & high & $\begin{array}{l}\text { high in placenta-MSCs, low in } \\
\text { UC-MSCs }\end{array}$ \\
\hline Morphology & larger & normal & normal \\
\hline Apoptosis tolerance & not high & high & not high \\
\hline
\end{tabular}

TABle 2: Osteogenic differentiation factors.

\begin{tabular}{lc}
\hline Protocols & Reference \\
\hline $\begin{array}{l}0.01 \mu \mathrm{M} \text { 1,25-dihydroxyvitamin } \mathrm{D} 3,50 \mu \mathrm{M} \\
\text { ascorbate-2-phosphate, } 10 \mathrm{mM} \beta \text {-glycerophosphate }\end{array}$ & {$[26,113]$} \\
$10 \mathrm{mM} \beta$-glycerophosphate, $0.1 \mathrm{mM}$ ascorbic acid, & \\
$1 \mu \mathrm{M}$ dexamethasone and a pulsed electromagnetic & {$[80]$} \\
field (PEMF) & \\
$\begin{array}{l}50 \mu \mathrm{g} / \mathrm{mL} \text { ascorbic } 2 \text { phosphate, } 10^{-8} \mathrm{mM} \\
\text { dexamethasone and } 10 \mathrm{mM} \beta \text {-glycerol-phosphate and }\end{array}$ & {$[92]$} \\
$\begin{array}{l}\text { Matrigel } \\
\begin{array}{l}3 \mathrm{D} \text { type I collagen matrices and } 10 \% \text { or } 12 \% \text { uniaxial } \\
\text { cyclic tensile strain at } 1 \mathrm{~Hz} \text { for } 4 \mathrm{~h} / \text { day }\end{array}\end{array}$ \\
$\begin{array}{l}\text { Artificial extracellular matrices containing collagen and } \\
\text { chondroitin sulfate with hydrostatic pressure (HP) }\end{array}$ & {$[93]$} \\
\hline
\end{tabular}

induction have been investigated as well. In some studies, mechanical stress [79], pulsed electromagnetic field (PEMF) [80], and hydrostatic pressure (HP) [81] were added to the osteogenic factors, while in others these factors were used to stimulate osteogenic differentiation without osteogenic induction supplements.

Dexamethasone is a potent stimulator of in vitro osteogenesis and induces the expression of the runt-related transcription factor 2 (Runx2), Osterix (Osx), and bone matrix proteins [82]. Ascorbic acid and $\beta$-glycerophosphate increase type I collagen secretion [83].

Jansen and colleagues cultured BMSCs in osteogenic medium and treated them with a pulsed electromagnetic field (PEMF). PEMF treatment increased the intensity of osteogenic differentiation $[80,84]$. PEMF has been suggested to enhance DNA synthesis through which it affects in vitro proliferation and differentiation of bone cells $[85,86]$. During differentiation, it increases the bone marker gene expressions and also promotes calcified matrix production [87].

To investigate the effect of extracellular matrix (ECM) proteins on osteogenic differentiation of hMSCs, Salasznyk and coworkers coated tissue culture plates with repetitive collagen I and collagen IV, laminin-I, and vitronectin. These
ECM proteins were found in bone marrow. This study showed that culturing of hMSCs on purified vitronectin and collagen I without osteogenic medium was sufficient to induce osteogenic differentiation [88]. Collagen I has been suggested to induce calcification of the stromal cell matrix [89]. Both, collagen type I and vitronectin have been reported to promote osteogenic differentiation of MSCs [90].

Eslaminejad and colleagues coated plastic surfaces of culture plates with matrigel. Matrigel is composed of laminin, collagen IV, proteoglycan, heparin sulfate, entactin, nidogen, and growth factors like transforming growth factor beta (TGF-beta), epidermal growth factor (EGF), insulin-like growth factor 1, bovine fibroblast growth factor (bFGF), and platelet-derived growth factor (PDGF) [91]. These factors create a microenvironment that regulates the proliferation and differentiation of hMSCs. HMSCs were cultured on matrigel-coated and plastic surface and induced towards the osteogenic lineage. It has been reported that hMSCs on matrigel-coated culture plates showed significantly stronger osteogenic differentiation if compared to hMSCs on plastic surface [92].

In another study, MSCs were cultured in linear 3D type I collagen matrices and subjected to different uniaxial cyclic tensile strain for 7 or 14 days. The results of this study showed that BM-MSCs in 3D collagen matrices under cyclic strain can differentiate towards osteogenic lineage without the addition of osteogenic supplements [93]. Whereas Yourek and colleagues reported that shear stress stimulates MSCs towards an osteoblastic phenotype in the absence of chemical induction [79].

Hess and coworkers investigated the effect of hydrostatic pressure (HP) stimulation on MSCs seeded on collagenbased artificial extracellular matrices. They coated artificial extracellular matrices generated from collagen and chondroitin sulfate onto polycaprolactone-co-lactide substrates. MSCs were seeded and subjected to cyclic HP at various time points during 21 days to investigate the effects of biochemical, mechanical, and combined biochemical and mechanical stimulations. Both HP and coated artificial 


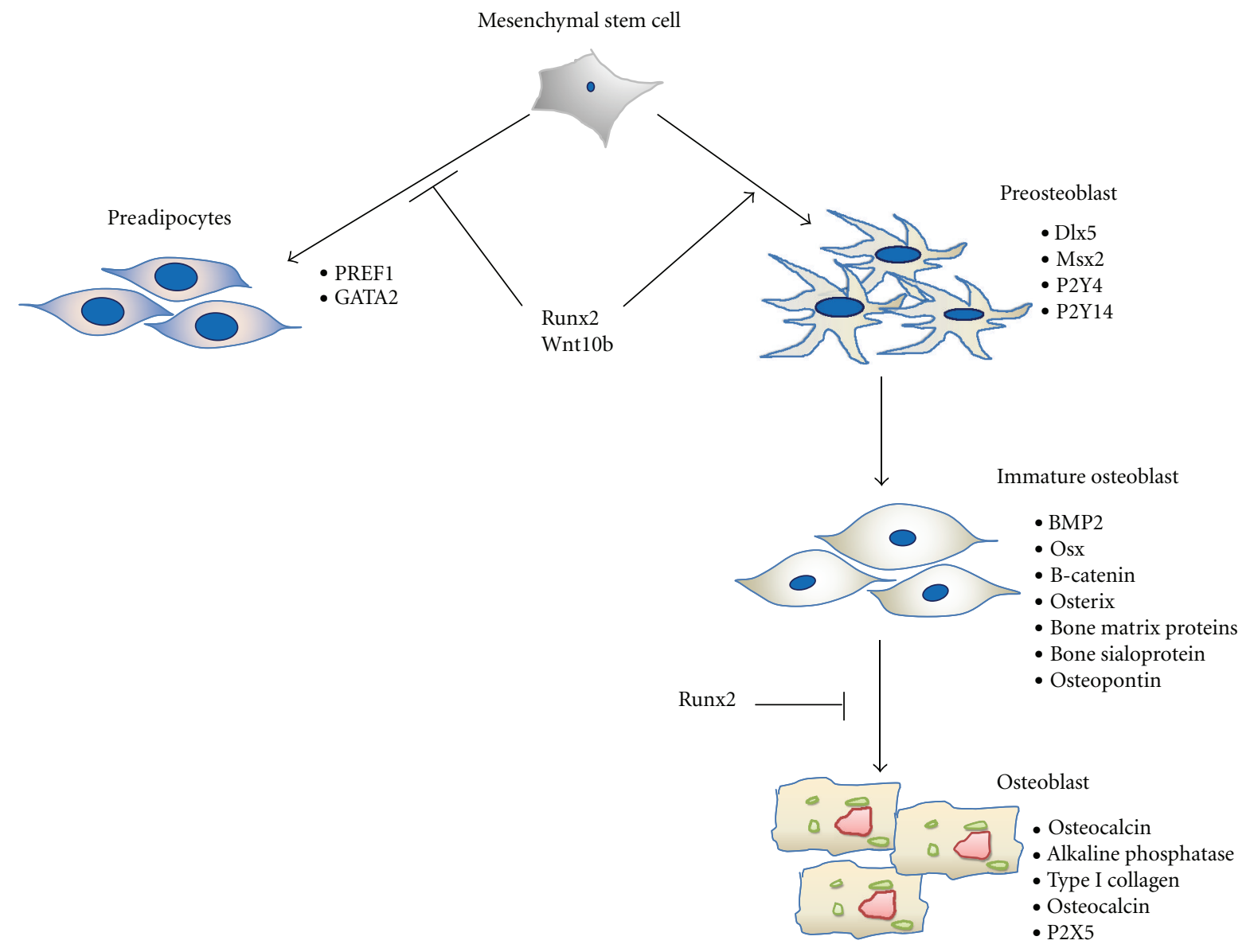

FIGURE 2: Change and differentiation of mesenchymal stem cells towards osteoblasts. Runx2 commits MSCs towards osteogenic lineage and inhibits adipogenic differentiation. After commitment, MSCs are differentiated into preosteoblasts which express runt-related transcription factor 2 (Runx2), distal-less homeobox 5 (Dlx5), and msh homeobox homologue 2 (Msx2). Preosteoblasts differentiate into immature osteoblasts. Immature osteoblasts express bone morphogenetic protein 2 (BMP2), Osterix (Osx), $\beta$-catenin, bone matrix proteins, bone sialoprotein, osteopontin and develop into mature osteoblasts. Mature osteoblasts express osteocalcin, alkaline phosphatase, and type I collagen.

matrices containing collagen and chondroitin sulfate promoted the osteogenic differentiation of MSCs individually, and a combination of both showed a synergistic effect on osteogenic induction of MSCs on scaffolds [81].

Sundelacruz and colleagues investigated the effect of a membrane potential on hMSCs differentiation towards the osteogenic lineage. Stem cells show a unique electrophysiological profile during their undifferentiated state [94]. Ionic currents and channels have been found to play a role in stem cell differentiation $[95,96]$. Sundelacruz showed that treatment of hMSCs with hyperpolarizing reagents increased the strength of osteogenic differentiation [97].

Taken together, all these studies show that chemical supplements and physical or mechanical factors can induce osteogenic differentiation of MSCs. A combination of these factors can be used to achieve an optimal differentiation potential of MSCs towards the osteogenic lineage.

The commitment and differentiation of MSCs towards osteogenic lineage is regulated by a certain group of factors
[98]. Among these factors, the initial and most specific marker is Runx2. Runx2 activates and regulates osteogenic differentiation by two independent signaling pathways via transforming growth factor-beta 1 (TGF $\beta 1$ ) and bone morphogenetic protein 2 (BMP2) $[99,100]$.

Along with Runx2, BMP2 and distal-less homeobox 5 (Dlx5) commit MSCs towards the osteogenic lineage. Commitment is the process that restricts MSCs to respond and undergo differentiation towards a specific lineage [101, 102]. In addition to the induction of osteogenic differentiation, Runx2 inhibits the differentiation of MSCs towards the adipogenic lineage [103]. BMP2 induces the expression of Osx independent of Runx2 [104].

Following commitment, MSCs are differentiated into preosteoblasts. Preosteoblast are elliptical in shape with an elongated nucleus and are capable of proliferation (see Figure 2). They express Runx2, D1x5, msh homeobox homologue 2 (Msx2), P2Y4 and P2Y14 [35, 105], and few markers of osteoblasts such as ALP, type I collagen, and 
osteopontin (OPN), but their expression is weaker than immature osteoblasts. Alkaline phosphatase is one of the early proteins and regulates bone mineralization.

$\beta$-catenin, Runx2, and Osx differentiate preosteoblasts into immature osteoblasts [106]. These cells are spindle shape (see Figure 2). They express bone matrix protein, bone sialoprotein, and OPN [106].

At later stages, Runx2 inhibits the maturation of osteoblasts [107]. Osx causes the terminal maturation of osteoblasts and induces osteocalcin expression [108]. When osteoblasts are completely differentiated they become cuboidal (see Figure 2) and produce a self-mineralized organic matrix [109]. The Golgi bodies and rough endoplasmic reticulum are well developed in mature osteoblasts as a result of increased need for protein production. The expression of OPN is reduced in mature osteoblasts; while the expression of other proteins such as P2X5 [35], alkaline phosphatase [110], collagen type I [110, 111], and osteocalcin [111] is increased.

2.5. Adipogenic Differentiation of Mesenchymal Stem Cells. In vivo MSCs presumably receive cytokine signals for differentiation [112], but in vitro they cannot get such signals from other cells. Therefore, certain induction factors are needed to induce MSCs towards the adipogenic lineage. To induce in vitro adipogenic differentiation of mesenchymal stem cells, three induction factors are required that are dexamethasone, indomethacin, and insulin $[26,113]$. Dexamethasone is a synthetic glucocorticoid agonist that acts as a potentstimulating agent during the differentiation of mesenchymal stem cells [114]. Indomethacin is a nonsteroidal antiinflammatory drug that induces adipogenic differentiation by activating PPAR $\gamma[115,116]$. Insulin promotes adipogenesis through at least four known mechanisms [117]. Insulin triggers adipogenesis by binding to IGF-1 as preadipocytes express more receptors for IGF-1 than for insulin [118]. Insulin binds to IGF-1 that results in the phosphorylation of cAMP response element-binding protein (CREB) through cAMP and phosphatidylinositol-3 kinase (PI3K) [119]. CREB is activated early to positively regulate the expression of CCAAT/enhancer binding protein alpha $(\mathrm{C} / \mathrm{EBP} \alpha)$ and peroxisome proliferator-activated receptor gamma $(\operatorname{PPAR} \gamma)$ [117]. Insulin also favors PPAR $y$ stimulation by inhibiting necdin that inhibits CREB stimulation of PPARy [117]. Through a serine/threonine protein kinase- (AKT/PKB-) mediated phosphorylation, insulin causes nuclear exclusion of forkhead transcription factor 1 (FOXO1) [120] and forkhead transcription factor 2 (FOXA2) that are both antiadipogenic transcription factors. GATA binding protein 2 (GATA2) is another target of AKT/PKB-mediated phosphorylation [121]. As these factors favor adipogenic differentiation of MSCs, MSCs become committed toward the adipogenic lineage. Following commitment, various transcription factors are activated that result in the adipogenic phenotype [122].

The treatment of MSCs with the above-mentioned induction factors results in an increased CREB phosphorylation that in turn transcriptionally activates $\mathrm{C} / \mathrm{EBP} \beta$
[121]. The induction of $\mathrm{C} / \mathrm{EBP} \beta$ leads to the activation of C/EBP $\alpha$ and Kruppel-like factor 5 (KLF5) [122], which in turn directly induce many adipocyte genes and specifically PPAR $y[123,124]$. PPAR $\gamma$ is a key player in adipogenesis. It is not only necessary for adipogenesis [125] but also needed for maintaining the differentiated state [126]. After commitment, the expression of these factors differentiates committed MSCs to preadipocytes.

Preadipocytes are flat phase-dark spindle-shaped cells (see Figure 3). In culture, the appearance of these cells is similar to fibroblasts or smooth muscle cells. Preadipocyte factor 1 (Pref- 1 ) is a transmembrane protein and is highly expressed in these cells. They also express Gata2 [127]. The expression of these markers is completely abolished in mature adipocytes [127, 128].

The preadipocytes are differentiated into early adipocytes. Early adipocytes become spherical in shape (see Figure 3). These cells express adipocyte determination and differentiation factor (ADD1), C/EBP $\beta$, KLF5, PPAR $\gamma$, lipoprotein lipase (LPL), leptin, and adiponectin [128] as key molecules.

Adipocytes are round in shape with large perilipincoated lipid droplets that displace nuclei to the cell periphery (see Figure 3). These cells acquire cell arrest, sensitivity for insulin, and expression of adipokines. $\operatorname{PPAR} \gamma, \mathrm{C} / \mathrm{EBP} \alpha$, adiponectin, adipsin, adipocyte Protein 2 (aP2), and purinergic receptor P2Y, G-protein coupled, 11 (P2Y11) [35] are expressed by mature adipocytes.

2.6. Key Factors Controlling the Balance between Adipogenesis and Osteogenesis. Summarizing the above-mentioned findings, some factors were found to be upregulated in adipogenesis but downregulated in osteogenesis or vice versa. These can be hypothesized to be key factors triggering differentiation into the adipogenic or osteogenic lineage (see Figure 4) [129]. An increasing expression of P2X6 was found during adipogenesis and a decreasing expression of the same factors in osteogenesis [35]. Leukemia inhibitor factor (LIF) and dexamethasone induce adipogenic differentiation and at the same time inhibit the maturation of osteoblasts $[130,131]$. Similarly, some osteogenic differentiation triggering factors such as Runx2, Wnt10b, and bone morphogenetic proteins (BMPs) can inhibit adipocytes differentiation [132, 133]. Recently, secreted frizzled-related protein 1 (sFRP-1) was demonstrated to initiate adipogenesis and inhibit osteogenesis, and delta-like 1 (preadipocyte) factor 1 oppositely induces osteogenesis but inhibit adipogenesis through Wnt and NF- $\kappa \mathrm{B}$ signaling [134]. Constitutively active RhoA can induce hMSCs into osteoblasts; however, negatively expressed dominantRhoA committed those MSCs to become adipocytes [135]. Transforming growth factors (TGF- $\beta$ s) can trigger MSCs to commit towards myocytes and chondrocytes while inhibiting adipocyte, osteocyte, and endothelial cell differentiation $[136,137]$. Fibroblast grow factors (FGFs) and plateletderived growth factor (PDGF) are involved in the differentiation into adipogenic, osteogenic, and chondrogenic 

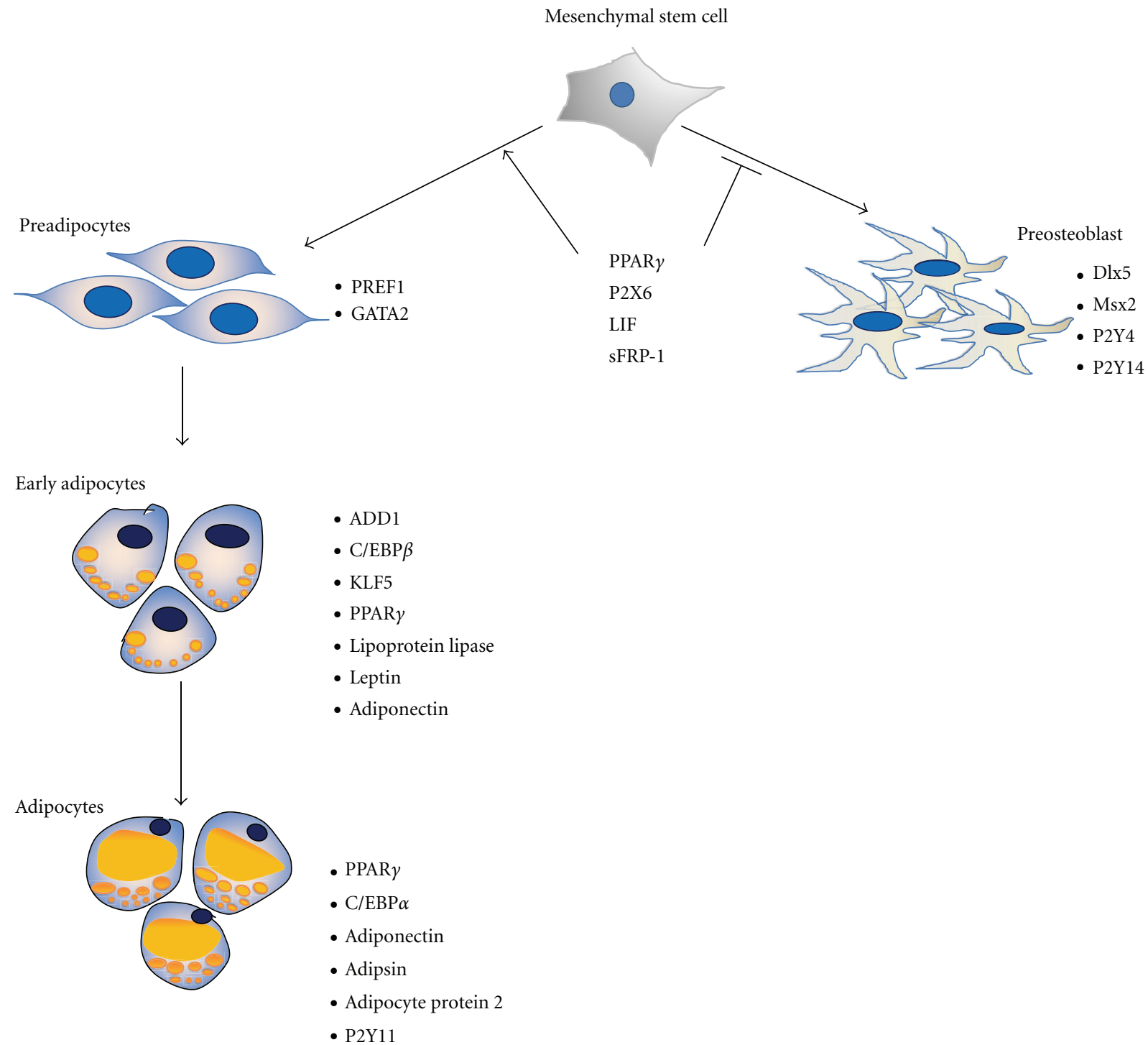

FIGURE 3: Differentiation of mesenchymal stem cells towards adipocytes. Peroxisome proliferator-activated receptor gamma (PPAR $\gamma$ ) commits MSCs towards adipogenic lineage. Preadipocyte factor 1 (Pref-1) and GATA binding protein 2 (Gata2) are expressed in preadipocyte. In early adipocyte determination and differentiation factor (ADD1), CCAAT/enhancer binding protein beta (C/EBP $\beta$ ), Kruppel-like factor 5 (KLF5), PPAR $\gamma$, lipoprotein lipase (LPL), leptin and adiponectin are expressed. The early adipocyte develops into the adipocyte that expresses $\mathrm{PPAR} \gamma, \mathrm{C} / \mathrm{EBP} \alpha$ adiponectin, adipsin, adipocyte protein 2, and purinergic receptor P2Y 11 (P2Y11).

lineages [138]. Physico-mechanical features by extracellular matrix components can influence MSCs fate too. A soft local structural geometry can trigger adipogenic differentiation, while osteoblasts can be differentiated from MSCs in stiff scaffolds $[76,139,140]$. Cell-cell contact between MSCs also has an impact on their fate. Usually adipogenic differentiation requires larger number of cells than the initiation of osteogenic differentiation [35]. The MSCs microenvironment controls differentiation due to changes of cell shape and the cytoskeleton [139]. Finally, physicochemical factors such as oxygen tension, ionic strength, and $\mathrm{pH}$ can also mediate stem cell proliferation and differentiation [141$143]$.

\section{MSCs in Clinical Trials}

Human MSCs show potential for various therapeutic applications and have attracted the attention for clinical investigations. In addition to their multipotency, these cells secret immunosuppressive cytokines [144]. The low-immune characteristics make them a suitable candidate cell for allogenic therapeutic use, without stimulating the immune response in immunocompetent patients $[145,146]$. The hMSCs are expected to repair damaged tissue or stimulate the damaged tissue through cytokines to regenerate themself. At present these cells are being investigated in many clinical studies at different phases to treat various diseases such as osteogenesis 


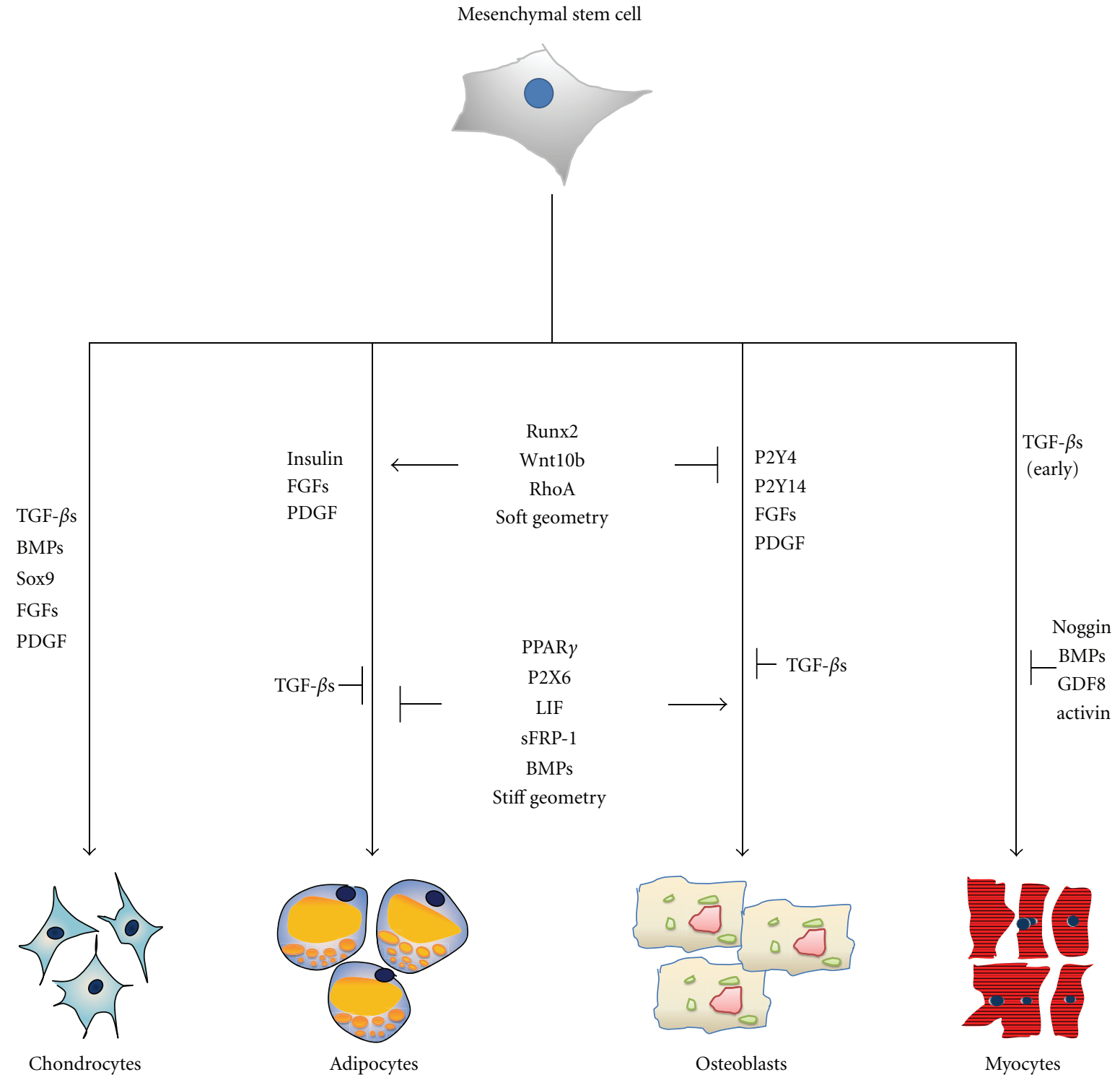

FIGURE 4: Key molecules regulating adipogenesis and osteogenesis in mesenchymal stem cells. Runx2, Wnt10b, RhoA, and soft geometry can induce osteogenesis while inhibiting adipogenesis. In contrast to this, PPAR $\gamma$, P2X6, LIF, sFRP-1, BMPs, as well as stiff geometry can trigger adipogenesis while inhibiting osteogenesis. Next to these key molecules, FGFs and PDGF can induce both adipogenesis and osteogenesis. Insulin can induce adipogenesis, while P2Y4 and P2Y14 can induce osteogenesis and TGF- $\beta$ s can inhibit both adipogenic and osteogenic differentiation. The key molecules for the other major mesenchymal lineages are listed in the left-hand part of the figure for chondrogenesis and in the right-hand part for myogenesis. TGF- $\beta$ s, BMPs, Sox9, FGFs, and PDGF are key triggers of chondrogenic differentiation. TGF- $\beta$ s can induce early myogenesis, while Noggin, BMPs, GDF8, and activin can inhibit myogenic differentiation.

imperfecta, chronic and acute myocardial infarction, and graft versus host disease [147-149]. The public clinical trial database shows 123 studies investigating MSCs for a variety of therapeutic purposes [150]. The majorities of these studies are in phase I, phase II, or are a mixture of phase I and phase II [150].

Interestingly the clinical studies do not only address diseases to be expected to be treated by MSCs, but all kinds of diseases with cancers being the most prominent one.

At the moment, there are approximately 3000 studies with stem cells, and most of them seem to be effective due to indirect effects such as paracrine signaling or immunomodulatory effect of stimulating local progenitor cells to repair the damaged tissue. There can be no doubt that stem cells will be a key tool in regenerative medicine in the future.

\section{Conclusion}

Human MSCs will be an attractive source for regenerative medicine approaches in the future. They are already tested for new therapies for many diseases such as bone fracture repair, cartilage repair, and cardiovascular diseases. Other 
illnesses such as diabetes, stroke, multiple sclerosis, amyotrophic lateral sclerosis (ALS), and cancer are on the way as well. Inspiringly, more than 3000 clinical trials are performed for utilizing stem cells to treat above diseases at the moment. But astonishingly most of them, actually more than 2500 are for cancer $(>2,500)$, thus not for an approach where repair is predominant, as could be expected from stem cell treatments. Most of these approaches are still in Phase I or Phase II and provide at least some new insight. However, it must be considered carefully why most of them have only short-term positive effects, and long-term benefits are missing for nearly all stem cell therapies at the moment. In order to solve this problem, more in-depth investigations are required.

Stem cells have paracrine effects on the neighboring progenitor and somatic cells, whose underlying mechanisms are still unclear. In addition, some of their beneficial properties seem to be due to immunomodulatory effects. This is an astonishing result because before, the expected effect of stem cells was the repair of damaged tissues or organs by differentiating into the cells whichever form and are functional in the targeted tissue or organ. This, of course, is still a main goal. However, how to stimulate and induce stem cells properly to achieve the desired differentiation and repair of the tissue obviously cannot be pinpointed to currently good enough. Therefore, key molecules which regulate and determine stem cell fate (some shown in Figure 4) are vital for addressing this question. In addition, the microenvironment of the cells seems to be equally important for improving stem cell therapies. Here a mimic of the stem cell niche in vitro is the objective. It might be necessary to fully induce stem cell differentiation for example, by modifying key molecule ligands or by providing the necessary physic-chemical environment to differentiate and stabilize the differentiated cells. For this, more work should be done to understand the underlying mechanisms of interaction between stem cells and their microenvironment. Last not least, in light of the reprogramming possibilities which have been discovered in the last five years, the plasticity of mesenchymal stem cell must be reinvestigated and reevaluated. Taken together, mesenchymal stem cells might give us possibilities for repair of damages tissues and organs in the future which we are just starting to discover.

\section{Abbreviations}

ADD1: Adipocyte determination and differentiation factor

AT: $\quad$ Adipose tissue

bFGF: Fibroblast growth factor

BM: Bone marrow

BMP: Bone morphogenetic protein

CCNB2: Cyclin B2

CDCA8: Cell division cycle associated 8

CREB: cAMP response element-binding protein

CTGF: Connective tissue growth factor

Dlx5: Distal-less homeobox 5

ECM: Extracellular matrix
EGF: $\quad$ Epidermal growth factor

ESCs: Embryonic stem cells

FGF: $\quad$ Fibroblast growth factor

FOXO: Forkhead transcription factor

GATA2: GATA binding protein 2

HP: $\quad$ Hydrostatic pressure

HSCs: Hematopoietic stem cells

iPS: $\quad$ Induced pluripotent stem cells

ISCT: International Society of Cellular Therapy

KLF5: $\quad$ Kruppel-like factor 5

LIF: Leukemia inhibitor factor

LPL: $\quad$ Lipoprotein lipase

MEST: Mesoderm-specific transcript homolog

MSCs: Mesenchymal stem cells

Msx2: $\quad$ Msh homeobox homologue 2

OPN: Osteopontin

Osx: $\quad$ Osterix

PAI-1: Plasminogen activator inhibitor-1

PB: $\quad$ Peripheral blood

PDGF: Platelet-derived growth factor

PEMF: $\quad$ Pulsed electromagnetic field

Pref-1: $\quad$ Preadipocyte factor 1

Runx2: Runt-related transcription factor 2

sFRP-1: $\quad$ Secreted frizzled-related protein 1

SM: $\quad$ Skeleton muscle

TGF-beta: Transforming growth factor beta

UC: Umbilical cord

UCB: Umbilical cord blood.

\section{Acknowledgments}

This work was supported by BMBF-AIF, AdiPaD; FKZ: 1720X06 for E. Tobiasch and China Scholarship Council (CSC) no. 20100602024; Helmholtz Space Life Research Sciences School, Institute of Aerospace Medicine, German Aerospace Center (DLR) for Y. Zhang; Higher Education Commission Pakistan and DAAD for D. Khan.

\section{References}

[1] J. A. Thomson, J. Itskovitz-Eldor, S. S. Shapiro et al., "Embryonic stem cell lines derived from human blastocysts," Science, vol. 282, no. 5391, pp. 1145-1147, 1998.

[2] M. F. Pittenger, A. M. Mackay, S. C. Beck et al., "Multilineage potential of adult human mesenchymal stem cells," Science, vol. 284, no. 5411, pp. 143-147, 1999.

[3] D. C. Ding, W. C. Shyu, and S. Z. Lin, "Mesenchymal stem cells," Cell Transplant, vol. 20, pp. 5-14, 2011.

[4] M. Ogawa, "Differentiation and proliferation of hematopoietic stem cells," Blood, vol. 81, no. 11, pp. 2844-2853, 1993.

[5] D. Metcalf, "On hematopoietic stem cell fate," Immunity, vol. 26, no. 6, pp. 669-673, 2007.

[6] K. Takahashi and S. Yamanaka, "Induction of pluripotent stem cells from mouse embryonic and adult fibroblast cultures by defined factors," Cell, vol. 126, no. 4, pp. 663-676, 2006.

[7] K. Takahashi, K. Tanabe, M. Ohnuki et al., "Induction of pluripotent stem cells from adult human fibroblasts by defined factors," Cell, vol. 131, no. 5, pp. 861-872, 2007. 
[8] M. Wernig, A. Meissner, R. Foreman et al., "In vitro reprogramming of fibroblasts into a pluripotent ES-cell-like state," Nature, vol. 448, no. 7151, pp. 318-324, 2007.

[9] J. Yu, M. A. Vodyanik, K. Smuga-Otto et al., "Induced pluripotent stem cell lines derived from human somatic cells," Science, vol. 318, no. 5858, pp. 1917-1920, 2007.

[10] J. B. Kim, B. Greber, M. J. Arazo-Bravo et al., "Direct reprogramming of human neural stem cells by OCT4," Nature, vol. 461, no. 7264, pp. 649-653, 2009.

[11] S. Eminli, A. Foudi, M. Stadtfeld et al., "Differentiation stage determines potential of hematopoietic cells for reprogramming into induced pluripotent stem cells," Nature Genetics, vol. 41, no. 9, pp. 968-976, 2009.

[12] P. S. Knoepfler, "Deconstructing stem cell tumorigenicity: a roadmap to safe regenerative medicine," Stem Cells, vol. 27, no. 5, pp. 1050-1056, 2009.

[13] T. Zhao, Z. N. Zhang, Z. Rong, and Y. Xu, "Immunogenicity of induced pluripotent stem cells," Nature, vol. 474, no. 7350, pp. 212-215, 2011.

[14] A. J. Nauta and W. E. Fibbe, "Immunomodulatory properties of mesenchymal stromal cells," Blood, vol. 110, no. 10, pp. 3499-3506, 2007.

[15] E. B. Maria, L. Franco, and E. F. Willem, "Mesenchymal stromal cells: a novel treatment modality for tissue repair," Annals of the New York Academy of Sciences, vol. 1176, pp. 101-117, 2009.

[16] H. K. Salem and C. Thiemermann, "Mesenchymal stromal cells: current understanding and clinical status," Stem Cells, vol. 28, no. 3, pp. 585-596, 2010.

[17] L. Jackson, D. Jones, P. Scotting, and V. Sottile, "Adult mesenchymal stem cells: differentiation potential and therapeutic applications," Journal of Postgraduate Medicine, vol. 53, no. 2, pp. 121-127, 2007.

[18] M. Breitbach, T. Bostani, W. Roell et al., "Potential risks of bone marrow cell transplantation into infarcted hearts," Blood, vol. 110, no. 4, pp. 1362-1369, 2007.

[19] P. Bianco, P. G. Robey, and P. J. Simmons, "Mesenchymal stem cells: revisiting history, concepts, and assays," Cell Stem Cell, vol. 2, no. 4, pp. 313-319, 2008.

[20] Y. Jiang, B. N. Jahagirdar, R. L. Reinhardt et al., "Pluripotency of mesenchymal stem cells derived from adult marrow," Nature, vol. 418, no. 7146, pp. 41-49, 2007.

[21] W. Wagner and A. D. Ho, "Mesenchymal stem cell preparations-comparing apples and oranges," Stem Cell Reviews, vol. 3, no. 4, pp. 239-248, 2007.

[22] Y. Zhang and E. Tobiasch, "The role of purinergic receptors in stem cells in their derived consecutive tissues," in Adult Stem Cell Standardization, P. di Nardo, Ed., pp. 73-98, River Publishers, 2011.

[23] D. J. Prockop, "Marrow stromal cells as stem cells for nonhematopoietic tissues," Science, vol. 276, no. 5309, pp. 71-74, 1997.

[24] M. Kassem and B. M. Abdallah, "Human bone-marrowderived mesenchymal stem cells: biological characteristics and potential role in therapy of degenerative diseases," Cell and Tissue Research, vol. 331, no. 1, pp. 157-163, 2008.

[25] P. A. Zuk, M. Zhu, H. Mizuno et al., "Multilineage cells from human adipose tissue: implications for cell-based therapies," Tissue Engineering, vol. 7, no. 2, pp. 211-228, 2001.

[26] P. A. Zuk, M. Zhu, P. Ashjian et al., "Human adipose tissue is a source of multipotent stem cells," Molecular Biology of the Cell, vol. 13, no. 12, pp. 4279-4295, 2002.

[27] U. Nöth, A. M. Osyczka, R. Tuli, N. J. Hickok, K. G. Danielson, and R. S. Tuan, "Multilineage mesenchymal differentiation potential of human trabecular bone-derived cells," Journal of Orthopaedic Research, vol. 20, no. 5, pp. 1060-1069, 2002.

[28] E. Tobiasch, "Adult human mesenchymal stem cells as source for future tissue engineering," in Forschungsspitzen und Spitzenforschung, C. Zacharias, K. W. Ter Horst, K.-U. Witt et al., Eds., Springverlag, 2008.

[29] O. K. Lee, T. K. Kuo, W. M. Chen, K. D. Lee, S. L. Hsieh, and T. $\mathrm{H}$. Chen, "Isolation of multipotent mesenchymal stem cells from umbilical cord blood," Blood, vol. 103, no. 5, pp. 16691675, 2004.

[30] G. Kögler, S. Sensken, J. A. Airey et al., "A new human somatic stem cell from placental cord blood with intrinsic pluripotent differentiation potential," Journal of Experimental Medicine, vol. 200, no. 2, pp. 123-135, 2004.

[31] R. Hass, C. Kasper, S. Bohm, and R. Jacobs, "Different populations and sources of human mesenchymal stem cells (MSC): a comparison of adult and neonatal tissue-derived MSC," Cell Communication and Signaling, vol. 9, p. 12, 2011.

[32] K. Mareschi, E. Biasin, W. Piacibello, M. Aglietta, E. Madon, and F. Fagioli, "Isolation of human mesenchymal stem cells: bone marrow versus umbilical cord blood," Haematologica, vol. 86, no. 10, pp. 1099-1100, 2001.

[33] M. Dominici, K. Le Blanc, I. Mueller et al., "Minimal criteria for defining multipotent mesenchymal stromal cells. The International Society for Cellular Therapy position statement," Cytotherapy, vol. 8, no. 4, pp. 315-317, 2006.

[34] N. Zippel, M. Schulze, and E. Tobiasch, "Biomaterials and mesenchymal stem cells for regenerative medicine," Recent Patents on Biotechnology, vol. 4, no. 1, pp. 1-22, 2010.

[35] N. Zippel, C. A. Limbach, and N. Ratajski, "Purinergic receptorsinfluence the differentiation of human mesenchymal stem cells," Stem Cells and Development. In press.

[36] G. Brooke, H. Tong, J. P. Levesque, and K. Atkinson, "Molecular trafficking mechanisms of multipotent mesenchymal stem cells derived from human bone marrow and placenta," Stem Cells and Development, vol. 17, no. 5, pp. 929-940, 2008.

[37] S. Barlow, G. Brooke, K. Chatterjee et al., "Comparison of human placenta- and bone marrow-derived multipotent mesenchymal stem cells," Stem Cells and Development, vol. 17, no. 6, pp. 1095-1107, 2008.

[38] S. Kern, H. Eichler, J. Stoeve, H. Klüter, and K. Bieback, "Comparative analysis of mesenchymal stem cells from bone marrow, umbilical cord blood, or adipose tissue," Stem Cells, vol. 24, no. 5, pp. 1294-1301, 2006.

[39] P. Shetty, K. Cooper, and C. Viswanathan, "Comparison of proliferative and multilineage differentiation potentials of cord matrix, cord blood, and bone marrow mesenchymal stem cells," Asian Journal of Transfusion Science, vol. 4, pp. 14-24, 2010.

[40] D. Baksh, L. Song, and R. S. Tuan, "Adult mesenchymal stem cells: characterization, differentiation, and application in cell and gene therapy," Journal of Cellular and Molecular Medicine, vol. 8, no. 3, pp. 301-316, 2004.

[41] L. L. Lu, Y. J. Liu, S. G. Yang et al., "Isolation and characterization of human umbilical cord mesenchymal stem cells with hematopoiesis-supportive function and other potentials," Haematologica, vol. 91, no. 8, pp. 1017-1028, 2006.

[42] L. Peng, Z. Jia, X. Yin et al., "Comparative analysis of mesenchymal stem cells from bone marrow, cartilage, and adipose tissue," Stem Cells and Development, vol. 17, no. 4, pp. 761-773, 2008. 
[43] B. M. Schipper, K. G. Marra, W. Zhang, A. D. Donnenberg, and J. P. Rubin, "Regional anatomic and age effects on cell function of human adipose-derived stem cells," Annals of Plastic Surgery, vol. 60, no. 5, pp. 538-544, 2008.

[44] Y. Y. Shi, R. P. Nacamuli, A. Salim, and M. T. Longaker, "The osteogenic potential of adipose-derived mesenchmal cells is maintained with aging," Plastic and Reconstructive Surgery, vol. 116, no. 6, pp. 1686-1696, 2005.

[45] V. van Harmelen, K. Röhrig, and H. Hauner, "Comparison of proliferation and differentiation capacity of human adipocyte precursor cells from the omental and subcutaneous adipose tissue depot of obese subjects," Metabolism, vol. 53, no. 5, pp. 632-637, 2004.

[46] G. Li, X. A. Zhang, H. Wang et al., "Comparative proteomic analysis of mesenchymal stem cells derived from human bone marrow, umbilical cord, and placenta: implication in the migration," Proteomics, vol. 9, no. 1, pp. 20-30, 2009.

[47] D. Baksh, R. Yao, and R. S. Tuan, "Comparison of proliferative and multilineage differentiation potential of human mesenchymal stem cells derived from umbilical cord and bone marrow," Stem Cells, vol. 25, no. 6, pp. 1384-1392, 2007.

[48] T. Deuse, M. Stubbendorff, K. Tang-Quan et al., "Immunogenicity and immunomodulatory properties of umbilical cord lining mesenchymal stem cells," Cell Transplantation, vol. 20, no. 5, pp. 655-667, 2011.

[49] Y. Kitagawa, M. Kobori, K. Toriyama, Y. Kamei, and S. Torii, "History of discovery of human adipose-derived stem cells and their clinical application," Japanese Journal of Plastic and Reconstructive Surgery, vol. 49, no. 10, pp. 1097-1104, 2006.

[50] D. A. De Ugarte, K. Morizono, A. Elbarbary et al., "Comparison of multi-lineage cells from human adipose tissue and bone marrow," Cells Tissues Organs, vol. 174, no. 3, pp. 101109, 2003.

[51] R. H. Lee, B. Kim, I. Choi et al., "Characterization and expression analysis of mesenchymal stem cells from human bone marrow and adipose tissue," Cellular Physiology and Biochemistry, vol. 14, no. 4-6, pp. 311-324, 2004.

[52] D. A. De Ugarte, Z. Alfonso, P. A. Zuk et al., "Differential expression of stem cell mobilization-associated molecules on multi-lineage cells from adipose tissue and bone marrow," Immunology Letters, vol. 89, no. 2-3, pp. 267-270, 2003.

[53] N. Ahmadian kia, A. R. Bahrami, M. Ebrahimi et al., "Comparative analysis of chemokine receptor's expression in mesenchymal stem cells derived from human bone marrow and adipose tissue," Journal of Molecular Neuroscience, vol. 4, pp. 178-185, 2010.

[54] W. Wagner, F. Wein, A. Seckinger et al., "Comparative characteristics of mesenchymal stem cells from human bone marrow, adipose tissue, and umbilical cord blood," Experimental Hematology, vol. 33, no. 11, pp. 1402-1416, 2005.

[55] S. M. Mueller and J. Glowacki, "Age-related decline in the osteogenic potential of human bone marrow cells cultured in three-dimensional collagen sponges," Journal of Cellular Biochemistry, vol. 82, no. 4, pp. 583-590, 2001.

[56] K. Stenderup, J. Justesen, C. Clausen, and M. Kassem, "Aging is associated with decreased maximal life span and accelerated senescence of bone marrow stromal cells," Bone, vol. 33, no. 6, pp. 919-926, 2003.

[57] J. K. Fraser, I. Wulur, Z. Alfonso, and M. H. Hedrick, "Fat tissue: an underappreciated source of stem cells for biotechnology," Trends in Biotechnology, vol. 24, no. 4, pp. 150-154, 2006.
[58] G. Ferrari, G. Cusella-De Angelis, M. Coletta et al., "Muscle regeneration by bone marrow-derived myogenic progenitors," Science, vol. 279, no. 5356, pp. 1528-1530, 1998.

[59] S. Gronthos, D. M. Franklin, H. A. Leddy et al., "Surface protein characterization of human adipose tissue-derived stromal cells," Journal of Cellular Physiology, vol. 189, no. 1, pp. 54-63, 2001.

[60] S. Wakitani, T. Saito, and A. I. Caplan, "Myogenic cells derived from rat bone marrow mesenchymal stem cells exposed to 5-azacytidine," Muscle and Nerve, vol. 18, no. 12, pp. 1417-1426, 1995.

[61] S. Heydarkhan-Hagvall, K. Schenke-Layland, J. Q. Yang et al., "Human adipose stem cells: a potential cell source for cardiovascular tissue engineering," Cells Tissues Organs, vol. 187, no. 4, pp. 263-274, 2008.

[62] W. C. Lee, J. P. Rubin, and K. G. Marra, "Regulation of $\alpha$ smooth muscle actin protein expression in adipose-derived stem cells," Cells Tissues Organs, vol. 183, no. 2, pp. 80-86, 2006.

[63] L. V. Rodríguez, Z. Alfonso, R. Zhang, J. Leung, B. Wu, and L. J. Ignarro, "Clonogenic multipotent stem cells in human adipose tissue differentiate into functional smooth muscle cells," Proceedings of the National Academy of Sciences of the United States of America, vol. 103, no. 32, pp. 12167-12172, 2006.

[64] V. Planat-Bénard, C. Menard, M. André et al., "Spontaneous cardiomyocyte differentiation from adipose tissue stroma cells," Circulation Research, vol. 94, no. 2, pp. 223-229, 2004.

[65] E. Pacary, H. Legros, S. Valable et al., "Synergistic effects of $\mathrm{CoCl}(2)$ and ROCK inhibition on mesenchymal stem cell differentiation into neuron-like cells," Journal of Cell Science, vol. 119, no. 13, pp. 2667-2678, 2006.

[66] A. Scuteri, M. Miloso, D. Foudah, M. Orciani, G. Cavaletti, and G. Tredici, "Mesenchymal stem cells neuronal differentiation ability: a real perspective for nervous system repair?" Current Stem Cell Research and Therapy, vol. 6, no. 2, pp. 8292, 2011.

[67] G. C. Kopen, D. J. Prockop, and D. G. Phinney, "Marrow stromal cells migrate throughout forebrain and cerebellum, and they differentiate into astrocytes after injection into neonatal mouse brains," Proceedings of the National Academy of Sciences of the United States of America, vol. 96, no. 19, pp. 10711-10716, 1999.

[68] M. J. Seo, S. Y. Suh, Y. C. Bae, and J. S. Jung, "Differentiation of human adipose stromal cells into hepatic lineage In vitro and in vivo," Biochemical and Biophysical Research Communications, vol. 328, no. 1, pp. 258-264, 2005.

[69] B. Pournasr, M. Mohamadnejad, M. Bagheri et al., "In vitro differentiation of human bone marrow mesenchymal stem cells into hepatocyte-like cells," Archives Of Iranian Medicine, pp. 244-249, 14.

[70] M. Wosnitza, K. Hemmrich, A. Groger, S. Gräber, and N. Pallua, "Plasticity of human adipose stem cells to perform adipogenic and endothelial differentiation," Differentiation, vol. 75, no. 1, pp. 12-23, 2007.

[71] C. Limbert and J. Seufert, "In vitro (re)programming of human bone marrow stromal cells toward insulin-producing phenotypes," Pediatric Diabetes, vol. 10, no. 6, pp. 413-419, 2009.

[72] O. Karnieli, Y. Izhar-Prato, S. Bulvik, and S. Efrat, "Generation of insulin-producing cells from human bone marrow mesenchymal stem cells by genetic manipulation," Stem Cells, vol. 25, no. 11, pp. 2837-2844, 2007. 
[73] W. B. Slayton and G. J. Spangrude, "Adult stem cell plasticity," in Adult Stem Cells, K. Turksen, Ed., pp. 1-3, Humana Press, NJ, USA, 2004.

[74] F. Guilak, D. M. Cohen, B. T. Estes, J. M. Gimble, W. Liedtke, and C. S. Chen, "Control of stem cell fate by physical interactions with the extracellular matrix," Cell Stem Cell, vol. 5, no. 1, pp. 17-26, 2009.

[75] A. J. Engler, S. Sen, H. L. Sweeney, and D. E. Discher, "Matrix elasticity directs stem cell lineage specification," Cell, vol. 126, no. 4, pp. 677-689, 2006.

[76] D. E. Discher, D. J. Mooney, and P. W. Zandstra, "Growth factors, matrices, and forces combine and control stem cells," Science, vol. 324, no. 5935, pp. 1673-1677, 2009.

[77] R. S. Tuan, G. Boland, and R. Tuli, "Adult mesenchymal stem cells and cell-based tissue engineering," Arthritis Research and Therapy, vol. 5, no. 1, pp. 32-45, 2003.

[78] N. Tremain, J. Korkko, D. Ibberson, G. C. Kopen, C. DiGirolamo, and D. G. Phinney, "MicroSAGE analysis of 2,353 expressed genes in a single cell-derived colony of undifferentiated human mesenchymal stem cells reveals mRNAS of multiple cell lineages," Stem Cells, vol. 19, no. 5, pp. 408-418, 2001.

[79] G. Yourek, S. M. McCormick, J. J. Mao, and G. C. Reilly, "Shear stress induces osteogenic differentiation of human mesenchymal stem cells," Regenerative Medicine, vol. 5, no. 5, pp. 713-724, 2010.

[80] J. H. W. Jansen, O. P. Van Der Jagt, B. J. Punt et al., "Stimulation of osteogenic differentiation in human osteoprogenitor cells by pulsed electromagnetic fields: an in vitro study," $B M C$ Musculoskeletal Disorders, vol. 11, pp. 188-199, 2010.

[81] R. Hess, T. Douglas, K. A. Myers et al., "Hydrostatic pressure stimulation of human mesenchymal stem cells seeded on collagen-based artificial extracellular matrices," Journal of Biomechanical Engineering, vol. 132, no. 2, pp. 1-6, 2010.

[82] M. Igarashi, N. Kamiya, M. Hasegawa, T. Kasuya, T. Takahashi, and M. Takagi, "Inductive effects of dexamethasone on the gene expression of Cbfal, Osterix and bone matrix proteins during differentiation of cultured primary rat osteoblasts," Journal of Molecular Histology, vol. 35, no. 1, pp. 3-10, 2004.

[83] A. Gupta, D. T. Leong, H. F. Bai, S. B. Singh, T. C. Lim, and D. W. Hutmacher, "Osteomaturation of adipose-derived stem cells required the combined action of vitamin D3, beta-glycerophosphate, and ascorbic acid," Biochemical and Biophysical Research Communications, vol. 362, pp. 17-24, 2007.

[84] M. T. Tsai, W. J. Li, R. S. Tuan, and W. H. Chang, "Modulation of osteogenesis in human mesenchymal stem cells by specific pulsed electromagnetic field stimulation," Journal of Orthopaedic Research, vol. 27, no. 9, pp. 1169-1174, 2009.

[85] P. Diniz, K. Shomura, K. Soejima, and G. Ito, "Effects of pulsed electromagnetic field (PEMF) stimulation on bone tissue like formation are dependent on the maturation stages of the osteoblasts," Bioelectromagnetics, vol. 23, no. 5, pp. 398-405, 2002.

[86] M. T. Tsai, W. H. S. Chang, K. Chang, R. J. Hou, and T. W. Wu, "Pulsed electromagnetic fields affect osteoblast proliferation and differentiation in bone tissue engineering," Bioelectromagnetics, vol. 28, no. 7, pp. 519-528, 2007.

[87] L. Fassina, L. Visai, F. Benazzo et al., "Effects of electromagnetic stimulation on calcified matrix production by SAOS-2 cells over a polyurethane porous scaffold," Tissue Engineering, vol. 12, no. 7, pp. 1985-1999, 2006.
[88] R. M. Salasznyk, W. A. Williams, A. Boskey, A. Batorsky, and G. E. Plopper, "Adhesion to vitronectin and collagen I promotes osteogenic differentiation of human mesenchymal stem cells," Journal of Biomedicine and Biotechnology, vol. 2004, no. 1, pp. 24-34, 2004.

[89] M. Mizuno and Y. Kuboki, "Osteoblast-related gene expression of bone marrow cells during the osteoblastic differentiation induced by type I collagen," Journal of Biochemistry, vol. 129, no. 1, pp. 133-138, 2001.

[90] A. K. Kundu and A. J. Putnam, "Vitronectin and collagen I differentially regulate osteogenesis in mesenchymal stem cells," Biochemical and Biophysical Research Communications, vol. 347, no. 1, pp. 347-357, 2006.

[91] S. Vukicevic, H. K. Kleinman, F. P. Luyten, A. B. Roberts, N. S. Roche, and A. H. Reddi, "Identification of multiple active growth factors in basement membrane Matrigel suggests caution in interpretation of cellular activity related to extracellular matrix components," Experimental Cell Research, vol. 202, no. 1, pp. 1-8, 1992.

[92] M. B. Eslaminejad, F. Bagheri, and E. Zomorodian, "Matrigel Enhances In vitro Bone Differentiation of Human Marrowderived Mesenchymal Stem Cells," Iranian Journal of Basic Medical Sciences, vol. 13, pp. 187-194, 2009.

[93] R. D. Sumanasinghe, S. H. Bernacki, and E. G. Loboa, "Osteogenic differentiation of human mesenchymal stem cells in collagen matrices: effect of uniaxial cyclic tensile strain on bone morphogenetic protein (BMP-2) mRNA expression," Tissue Engineering, vol. 12, no. 12, pp. 34593465, 2006.

[94] J. F. Heubach, E. M. Graf, J. Leutheuser et al., "Electrophysiological properties of human mesenchymal stem cells," Journal of Physiology, vol. 554, no. 3, pp. 659-672, 2004.

[95] T. Cho, J. H. Bae, H. B. Choi et al., "Human neural stem cells: electrophysiological properties of voltage-gated ion channels," NeuroReport, vol. 13, no. 11, pp. 1447-1452, 2002.

[96] S. Konig, V. Hinard, S. Arnaudeau et al., "Membrane hyperpolarization triggers myogenin and myocyte enhancer factor-2 expression during human myoblast differentiation," Journal of Biological Chemistry, vol. 279, no. 27, pp. 2818728196, 2004.

[97] S. Sundelacruz, M. Levin, and D. L. Kaplan, "Membrane potential controls adipogenic and osteogenic differentiation of mesenchymal stem cells," PLoS ONE, vol. 3, no. 11, Article ID e3737, 2008.

[98] P. Ducy and G. Karsenty, "Genetic control of cell differentiation in the skeleton," Current Opinion in Cell Biology, vol. 10, no. 5, pp. 614-619, 1998.

[99] K. S. Lee, H. J. Kim, Q. L. Li et al., "Runx2 is a common target of transforming growth factor $\beta 1$ and bone morphogenetic protein 2, and cooperation between Runx2 and Smad5 induces osteoblast-specific gene expression in the pluripotent mesenchymal precursor cell line C2C12," Molecular and Cellular Biology, vol. 20, no. 23, pp. 8783-8792, 2000.

[100] M. H. Lee, Y. J. Kim, H. J. Kim et al., "BMP-2-induced Runx2 expression is mediated by Dlx5, and TGF- $\beta 1$ opposes the BMP-2-induced osteoblast differentiation by suppression of Dlx5 expression," Journal of Biological Chemistry, vol. 278, no. 36, pp. 34387-34394, 2003.

[101] M. H. Lee, T. -G. Kwon, H. -S. Park, J. M. Wozney, and H.M. Ryoo, "BMP-2-induced Osterix expression is mediated by Dlx5 but is independent of Runx2," Biochemical and Biophysical Research Communications, vol. 309, no. 3, pp. 689-694, 2003. 
[102] T. Gaur, C. J. Lengner, H. Hovhannisyan et al., "Canonical WNT signaling promotes osteogenesis by directly stimulating Runx2 gene expression," Journal of Biological Chemistry, vol. 280, no. 39, pp. 33132-33140, 2005.

[103] H. Enomoto, T. Furuichi, A. Zanma et al., "Runx2 deficiency in chondrocytes causes adipogenic changes in vitro," Journal of Cell Science, vol. 117, no. 3, pp. 417-425, 2004.

[104] T. Matsubara, K. Kida, A. Yamaguchi et al., "BMP2 regulates osterix through Msx2 and Runx2 during osteoblast differentiation," Journal of Biological Chemistry, vol. 283, no. 43, pp. 29119-29125, 2008.

[105] S. I. Harada and G. A. Rodan, "Control of osteoblast function and regulation of bone mass," Nature, vol. 423, no. 6937, pp. 349-355, 2003.

[106] T. Komori, "Regulation of osteoblast differentiation by transcription factors," Journal of Cellular Biochemistry, vol. 99, no. 5, pp. 1233-1239, 2006.

[107] W. Liu, S. Toyosawa, T. Furuichi et al., "Overexpression of Cbfal in osteoblasts inhibits osteoblast maturation and causes osteopenia with multiple fractures," Journal of Cell Biology, vol. 155, no. 1, pp. 157-166, 2001.

[108] K. Nakashima, X. Zhou, G. Kunkel et al., "The novel zinc finger-containing transcription factor Osterix is required for osteoblast differentiation and bone formation," Cell, vol. 108, no. 1, pp. 17-29, 2002.

[109] J. E. Aubin and F. Liu, "The osteoblast lineage," in Principles of Bone Biology, J. P. Bilezikian, L. G. Raisz, and G. A. Rodan, Eds., pp. 51-68, Academic, San Diego, calif, USA, 1996.

[110] D. Pavlin, S. B. Dove, R. Zadro, and J. Gluhak-Heinrich, "Mechanical loading stimulates differentiation of periodontal osteoblasts in a mouse osteoinduction model: effect on type I collagen and alkaline phosphatase genes," Calcified Tissue International, vol. 67, no. 2, pp. 163-172, 2000.

[111] D. Pavlin, R. Zadro, and J. Gluhak-Heinrich, "Temporal pattern of stimulation of osteoblast-associated genes during mechanically-induced osteogenesis in vivo: early responses of osteocalcin and type I collagen," Connective Tissue Research, vol. 42, no. 2, pp. 135-148, 2001.

[112] S. Yamasaki, T. Nakashima, A. Kawakami et al., "Cytokines regulate fibroblast-like synovial cell differentiation to adipocyte-like cells," Rheumatology, vol. 43, no. 4, pp. 448-452, 2004.

[113] E. Tobiasch, "Differentiation potential of adult human mesenchymal stem cells," in Stem Cell Engineering, G.M. Artmann, J. Hescheler, and S. Minger, Eds., Springer, 2010.

[114] A. E. Grigoriadis, J. N. M. Heersche, and J. E. Aubin, "Differentiation of muscle, fat, cartilage, and bone from progenitor cells present in a bone-derived clonal cell population: effect of dexamethasone," Journal of Cell Biology, vol. 106, no. 6, pp. 2139-2151, 1988.

[115] J. M. Lehmann, J. M. Lenhard, B. B. Oliver, G. M. Ringold, and S. A. Kliewer, "Peroxisome proliferator-activated receptors $\alpha$ and $\gamma$ are activated by indomethacin and other non-steroidal anti-inflammatory drugs," Journal of Biological Chemistry, vol. 272, no. 6, pp. 3406-3410, 1997.

[116] S. Kim and N. Moustaid-Moussa, "Secretory, endocrine and autocrine/paracrine function of the adipocyte," Journal of Nutrition, vol. 130, no. 12, pp. 3110-3115, 2000.

[117] E. D. Rosen and O. A. MacDougald, "Adipocyte differentiation from the inside out," Nature Reviews Molecular Cell Biology, vol. 7, no. 12, pp. 885-896, 2006.

[118] P. J. Smith, L. S. Wise, R. Berkowitz, C. Wan, and C. S. Rubin, "Insulin-like growth factor-I is an essential regulator of the differentiation of 3T3-L1 adipocytes," Journal of Biological Chemistry, vol. 263, no. 19, pp. 9402-9408, 1988.

[119] G. M. Leinninger, C. Backus, M. D. Uhler, S. I. Lentz, and E. L. Feldman, "Phosphatidylinositol 3-kinase and Akt effectors mediate insulin-like growth factor-I neuroprotection in dorsal root ganglia neurons," FASEB Journal, vol. 18, no. 13, pp. 1544-1572, 2004.

[120] R. J. Southgate, C. R. Bruce, A. L. Carey et al., "PGC$1 \alpha$ gene expression is down-regulated by Akt-mediated phosphorylation and nuclear exclusion of FoxO1 in insulinstimulated skeletal muscle," FASEB Journal, vol. 19, no. 14, pp. 2072-2074, 2005.

[121] R. Menghini, V. Marchetti, M. Cardellini et al., "Phosphorylation of GATA2 by akt increases adipose tissue differentiation and reduces adipose tissue-related inflammation: a novel pathway linking obesity to atherosclerosis," Circulation, vol. 111, no. 15, pp. 1946-1953, 2005.

[122] T. C. Otto and M. D. Lane, "Adipose development: from stem cell to adipocyte," Critical Reviews in Biochemistry and Molecular Biology, vol. 40, no. 4, pp. 229-242, 2005.

[123] Y. Oishi, I. Manabe, K. Tobe et al., "Krüppel-like transcription factor KLF5 is a key regulator of adipocyte differentiation," Cell Metabolism, vol. 1, no. 1, pp. 27-39, 2005.

[124] E. D. Rosen, C. H. Hsu, X. Wang et al., "C/EBP $\alpha$ induces adipogenesis through PPAR $\gamma$ : a unified pathway," Genes and Development, vol. 16, no. 1, pp. 22-26, 2002.

[125] E. D. Rosen, C. J. Walkey, P. Puigserver, and B. M. Spiegelman, "Transcriptional regulation of adipogenesis," Genes and Development, vol. 14, no. 11, pp. 1293-1307, 2000.

[126] Y. Tamori, J. Masugi, N. Nishino, and M. Kasuga, "Role of peroxisome proliferator-activated receptor- $\gamma$ in maintenance of the characteristics of mature 3T3-L1 adipocytes," Diabetes, vol. 51, no. 7, pp. 2045-2055, 2002.

[127] Q. Tong, G. Dalgin, H. Xu, C. N. Ting, J. M. Leiden, and G. S. Hotamisligil, "Function of GATA transcription factors in preadipocyte-adipocyte transition," Science, vol. 290, no. 5489, pp. 134-138, 2000.

[128] F. M. Gregoire, C. M. Smas, and H. S. Sul, "Understanding adipocyte differentiation," Physiological Reviews, vol. 78, no. 3, pp. 783-809, 1998.

[129] J. M. Gimble, S. Zvonic, Z. E. Floyd, M. Kassem, and M. E. Nuttall, "Playing with bone and fat," Journal of Cellular Biochemistry, vol. 98, no. 2, pp. 251-266, 2006.

[130] J. N. Beresford, J. H. Bennett, C. Devlin, P. S. Leboy, and M. E. Owen, "Evidence for an inverse relationship between the differentiation of adipocytic and osteogenic cells in rat marrow stromal cell cultures," Journal of Cell Science, vol. 102, no. 2, pp. 341-351, 1992.

[131] D. Falconi, K. Oizumi, and J. E. Aubin, "Leukemia inhibitory factor influences the fate choice of mesenchymal progenitor cells," Stem Cells, vol. 25, no. 2, pp. 305-312, 2007.

[132] J. M. Gimble, C. Morgan, K. Kelly et al., "Bone morphogenetic proteins inhibit adipocyte differentiation by bone marrow stromal cells," Journal of Cellular Biochemistry, vol. 58, no. 3, pp. 393-402, 1995.

[133] S. Kang, C. N. Bennett, I. Gerin, L. A. Rapp, K. D. Hankenson, and O. A. MacDougald, "Wnt signaling stimulates osteoblastogenesis of mesenchymal precursors by suppressing CCAAT/enhancer-binding protein $\alpha$ and peroxisome proliferator-activated receptor $\gamma$," Journal of Biological Chemistry, vol. 282, no. 19, pp. 14515-14524, 2007.

[134] B. M. Abdallah and M. Kassem, "New factors controlling the balance between osteoblastogenesis and adipogenesis," Bone. In press. 
[135] R. McBeath, D. M. Pirone, C. M. Nelson, K. Bhadriraju, and C. S. Chen, "Cell shape, cytoskeletal tension, and RhoA regulate stem cell lineage commitment," Developmental Cell, vol. 6, no. 4, pp. 483-495, 2004.

[136] B. A. J. Roelen and P. Ten Dijke, "Controlling mesenchymal stem cell differentiation by TGF $\beta$ family members," Journal of Orthopaedic Science, vol. 8, no. 5, pp. 740-748, 2003.

[137] T. Watabe and K. Miyazono, "Roles of TGF- $\beta$ family signaling in stem cell renewal and differentiation," Cell Research, vol. 19, no. 1, pp. 103-115, 2009.

[138] F. Ng, S. Boucher, S. Koh et al., "PDGF, tgf-2. And FGF signaling is important for differentiation and growth of mesenchymal stem cells (mscs): transcriptional profiling can identify markers and signaling pathways important in differentiation of MSCs into adipogenic, chondrogenic, and osteogenic lineages," Blood, vol. 112, no. 2, pp. 295-307, 2008.

[139] J. S. Park, J. S. Chu, A. D. Tsou et al., "The effect of matrix stiffness on the differentiation of mesenchymal stem cells in response to TGF- $\beta$," Biomaterials, vol. 32, no. 16, pp. 39213930, 2011.

[140] M. Schulze and E. Tobiasch, "Artificial scaffolds and mesenchymal stem cells for hard tissue," Advances in Biochemical Engineering Biotechnology. In press.

[141] G. Pattappa, H. K. Heywood, J. D. de Bruijn, and D. A. Lee, "The metabolism of human mesenchymal stem cells during proliferation and differentiation," Journal of Cellular Physiology, vol. 226, pp. 2562-2570, 2010.

[142] G. B. Adams, K. T. Chabner, I. R. Alley et al., "Stem cell engraftment at the endosteal niche is specified by the calcium-sensing receptor," Nature, vol. 439, no. 7076, pp. 599-603, 2006.

[143] T. A. Mcadams, W. M. Miller, and E. T. Papoutsakis, "Variations in culture $\mathrm{pH}$ affect the cloning efficiency and differentiation of progenitor cells in ex vivo haemopoiesis," British Journal of Haematology, vol. 97, no. 4, pp. 889-895, 1997.

[144] S. Aggarwal and M. F. Pittenger, "Human mesenchymal stem cells modulate allogeneic immune cell responses," Blood, vol. 105, no. 4, pp. 1815-1822, 2005.

[145] A. Pansky, B. Roitzheim, and E. Tobiasch, "Differentiation potential of adult human mesenchymal stem cells," Clinical Laboratory, vol. 53, no. 1-2, pp. 81-84, 2007.

[146] D. I. Jung, J. Ha, B. T. Kang et al., "A comparison of autologous and allogenic bone marrow-derived mesenchymal stem cell transplantation in canine spinal cord injury," Journal of the Neurological Sciences, vol. 285, no. 1-2, pp. 67-77, 2009.

[147] E. M. Horwitz, P. L. Gordon, W. K. K. Koo et al., "Isolated allogeneic bone marrow-derived mesenchymal cells engraft and stimulate growth in children with osteogenesis imperfecta: implications for cell therapy of bone," Proceedings of the National Academy of Sciences of the United States of America, vol. 99, no. 13, pp. 8932-8937, 2002.

[148] J. F. Liu, B. W. Wang, H. F. Hung, H. Chang, and K. G. Shyu, "Human mesenchymal stem cells improve myocardial performance in a splenectomized rat model of chronic myocardial infarction," Journal of the Formosan Medical Association, vol. 107, no. 2, pp. 165-174, 2008.

[149] J. M. Hare, J. H. Traverse, T. D. Henry et al., "A randomized, double-blind, placebo-controlled, dose-escalation study of intravenous adult human mesenchymal stem cells (Prochymal) after acute myocardial infarction," Journal of the American College of Cardiology, vol. 54, no. 24, pp. 22772286, 2009.
[150] H. Mizuno, "Adipose-derived stem and stromal cells for cell-based therapy: current status of preclinical studies and clinical trials," Current Opinion in Molecular Therapeutics, vol. 12, no. 4, pp. 442-449, 2010. 

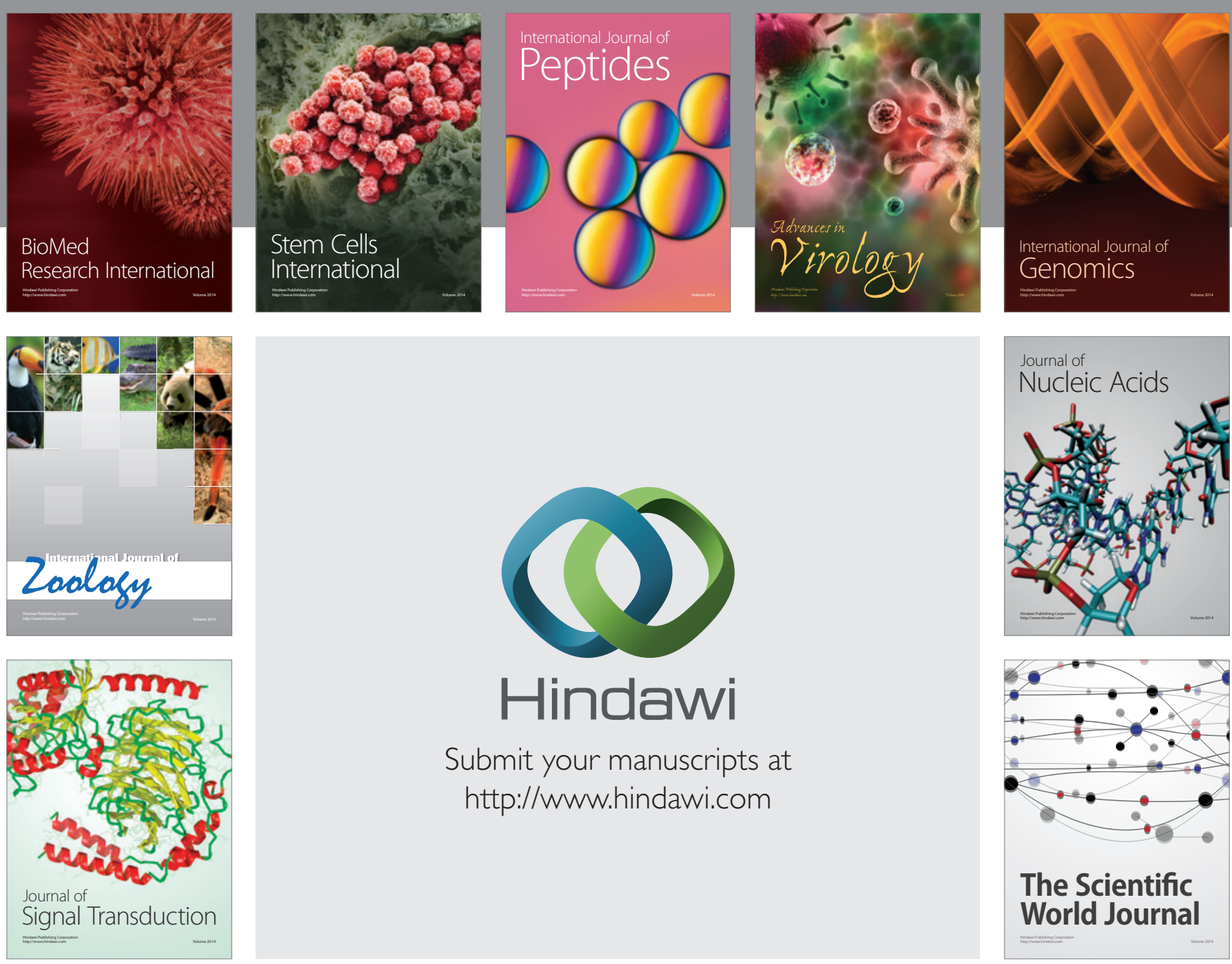

Submit your manuscripts at

http://www.hindawi.com
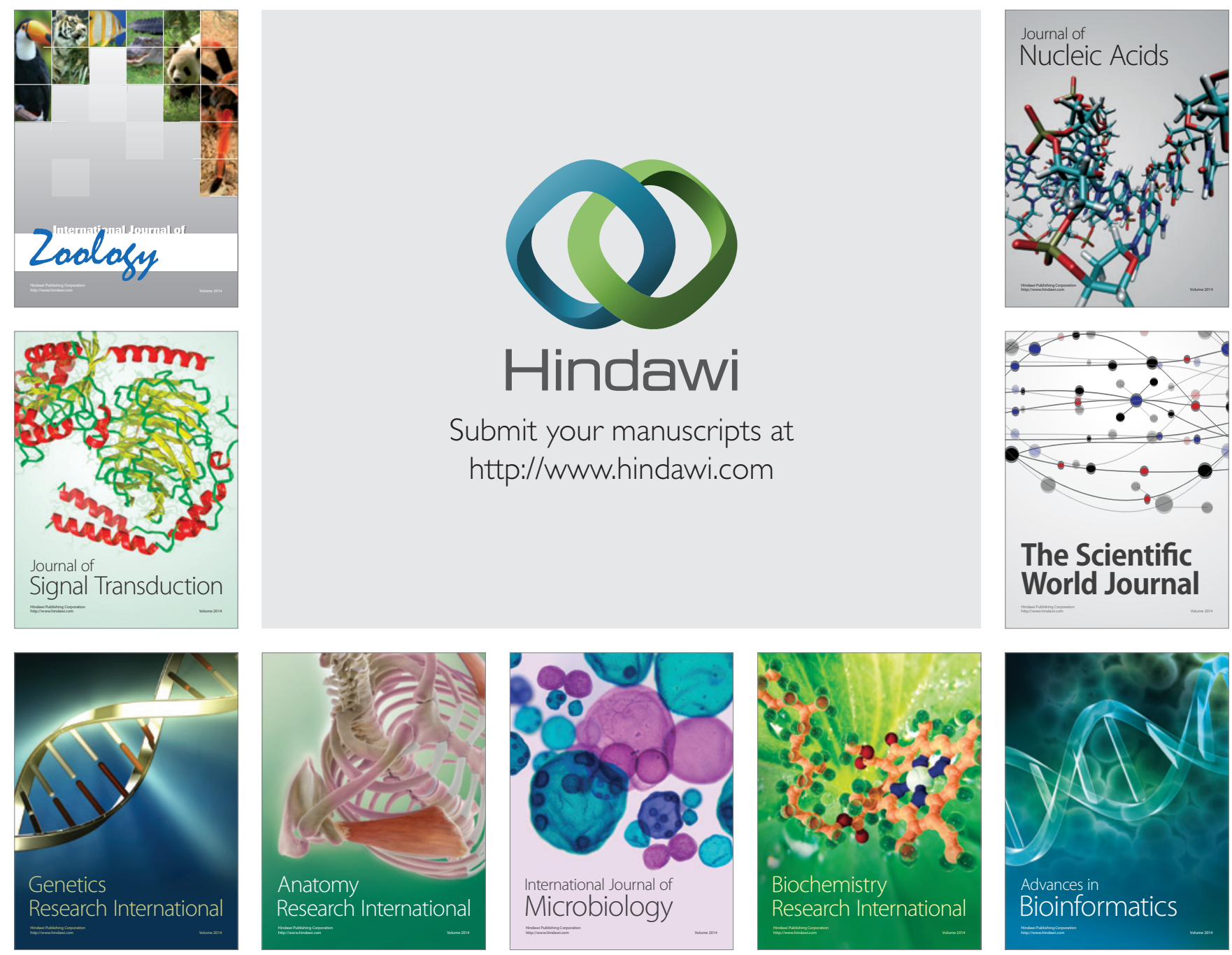

The Scientific World Journal
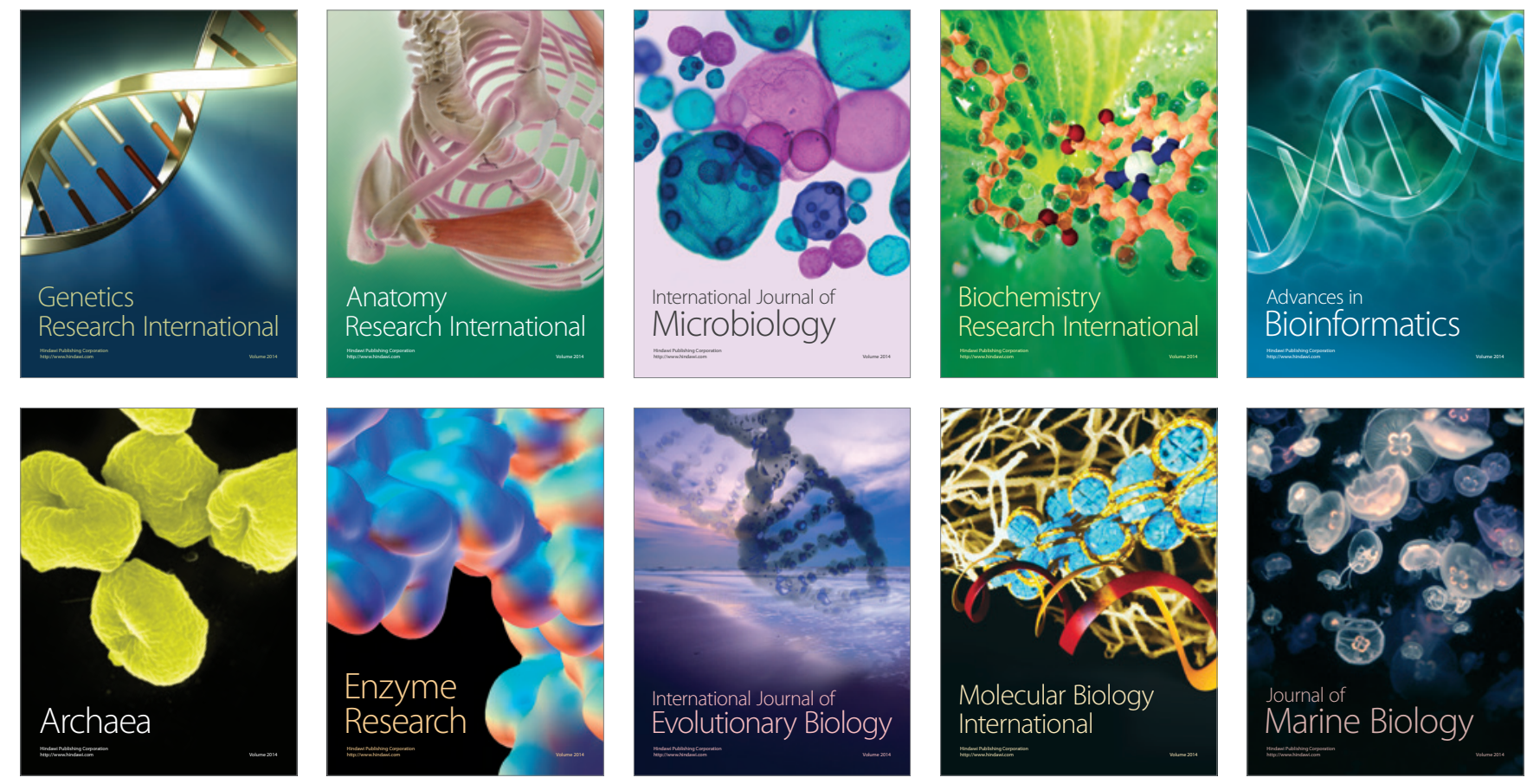